\title{
Can Regeneration of Green Ash (Fraxinus pennsylvanica) be Restored in Declining Woodlands in Eastern Montana?
}

\author{
Peter Lesica \\ Author is Senior Scientist at Conservation Biology Research, 929 Locust, Missoula, MT 59802, USA.
}

\begin{abstract}
Green ash (Fraxinus pennsylvanica Marsh.) dominates many deciduous woodlands at the western margin of its range in eastern Montana. Evidence suggests that the majority of green ash woodlands are in degraded condition with declining tree canopies and ground layers dominated by exotic grasses. The dense sod formed by these perennial grasses was hypothesized to interfere with green ash regeneration from seed. The purpose of this study was to test potential methods of restoring green ash regeneration in these declining woodlands. The effects of preseeding grazing and herbicide treatment and postgermination fertilizer on the recruitment, survival, and growth of green ash seedlings at each of four study sites typical of declining green ash woodlands in southeastern Montana were assessed. Six green ash trees at each of three sites were cut to examine the relationship of age, size, and health to sprouting ability and growth. Herbicide application had a positive effect on green ash recruitment and survival of green ash seedlings in woodlands with a dense sod of exotic grasses; seedling survival after 3-4 yr was ca. 10 times greater in herbicide-treated plots compared to controls or grazed plots. Seedlings grew slowly although fertilizer had a small positive effect on growth at one site. All coppiced trees produced basal sprouts, but sprout growth was severely curtailed at two of the three sites by deer browsing, suggesting that coppicing could increase tree canopy cover by replacing weakened trees with new and more vigorous boles and branches, but only where browsing by cattle and deer is reduced. Maintaining eastern Montana green ash woodlands in good condition should be given priority because restoration will be difficult.
\end{abstract}

\section{Resumen}

Green ash (Fraxinus pennsylvanica Marsh.) domina muchos bosques caducifolios en el margen occidental de su distribución en Montana oriental. La evidencia sugiere que la mayoría de los bosques de Green ash van en detrimento con la disminución de la cubierta aérea de los árboles y aumento de la cubierta del suelo por pastos exóticos. El denso césped formado por estos pastos perenes es lo que se cree que interfiere con la reproducción de green ash a partir de la semilla. El objetivo de este estudio fue la evaluación de métodos posibles de restauración para regenerar los bosques de green ash. Se evaluaron los tratamientos de los efectos del pastoreo antes de la siembra, y el uso de herbicidas; así como los fertilizantes después de la germinación en el establecimiento, sobrevivencia y crecimiento de las plantas de green ash en cada uno de los cuatro sitios típicos de los bosques de green ash que están disminuyendo en el Suroeste de Montana. Se cortaron seis árboles en tres de los sitios para examinar la relación de edad, el tamaño y la salud a la posibilidad de brotes y al crecimiento. La aplicación de herbicidas tuvo un efecto positivo sobre el establecimiento y sobrevivencia de las plántulas de green ash en bosques con un césped denso de pastos exóticos; sobrevivencia de las plántulas después de tres o cuatro años fue diez veces mayor en parcelas tratada con herbicidas en comparación con los controles o parcelas pastoreadas. Las plántulas crecieron muy lentamente aunque el fertilizante tuvo un efecto pequeño pero positivo en el crecimiento en un sitio. Todos los árboles de copa produjeron brotes basales, pero el crecimiento de los brotes fue restringido severamente en dos de los tres sitios debido al ramoneo por los venados. Esto indica que la poda de los arboles podría aumentar cubierta aérea del árbol reemplazando los árboles débiles con arboles nuevos y ramas más vigorosas, pero sólo cuando el ramoneo por ganado y los venados se reduzca. El mantenimiento de los bosques de green ash en buena condición en el este de Montana debe ser una prioridad debido que la restauración va a ser muy difícil.

Key Words: coppicing, exotic grasses, herbicide, livestock grazing, range margin, restoration

\section{INTRODUCTION}

Native deciduous woodlands dominated by green ash (Fraxinus pennsylvanica) occur on cool slopes and along small, usually ephemeral streams throughout the northwestern Great Plains. Green ash, a common component of the deciduous forest of eastern North America, is at the western, arid margin of its

Research was funded by the Bureau of Land Management, Montana Department of Fish, Wild life and Parks and the Grazing Land Conservation Initiative.

Correspondence: Peter Lesica, Conservation Biology Research, 929 Locust, Missoula, MT 59802, USA. Email: peter.lesica@mso.umt.edu

Manuscript received 8 March 2009; manuscript accepted 10 September 2009 range in eastern Montana (Great Plains Flora Association 1986). Although they occupy only $1-4 \%$ of the landscape (Boldt et al. 1978), green ash woodlands provide a disproportionately large component of biological diversity in this primarily steppe ecosystem. They are habitat for many wildlife species, including migratory songbirds, gallinaceous birds, and native ungulates (MacCracken and Uresk 1984; Hodorff and Sieg 1986; Rumble et al. 1998) as well as native deciduous forest plant species (Lesica 1989).

Evidence from throughout the northwestern Great Plains suggests that the majority of green ash woodlands are declining (Boldt et al. 1978; Lesica 1989, 2001). These communities in undisturbed condition had dense stratified canopies and 


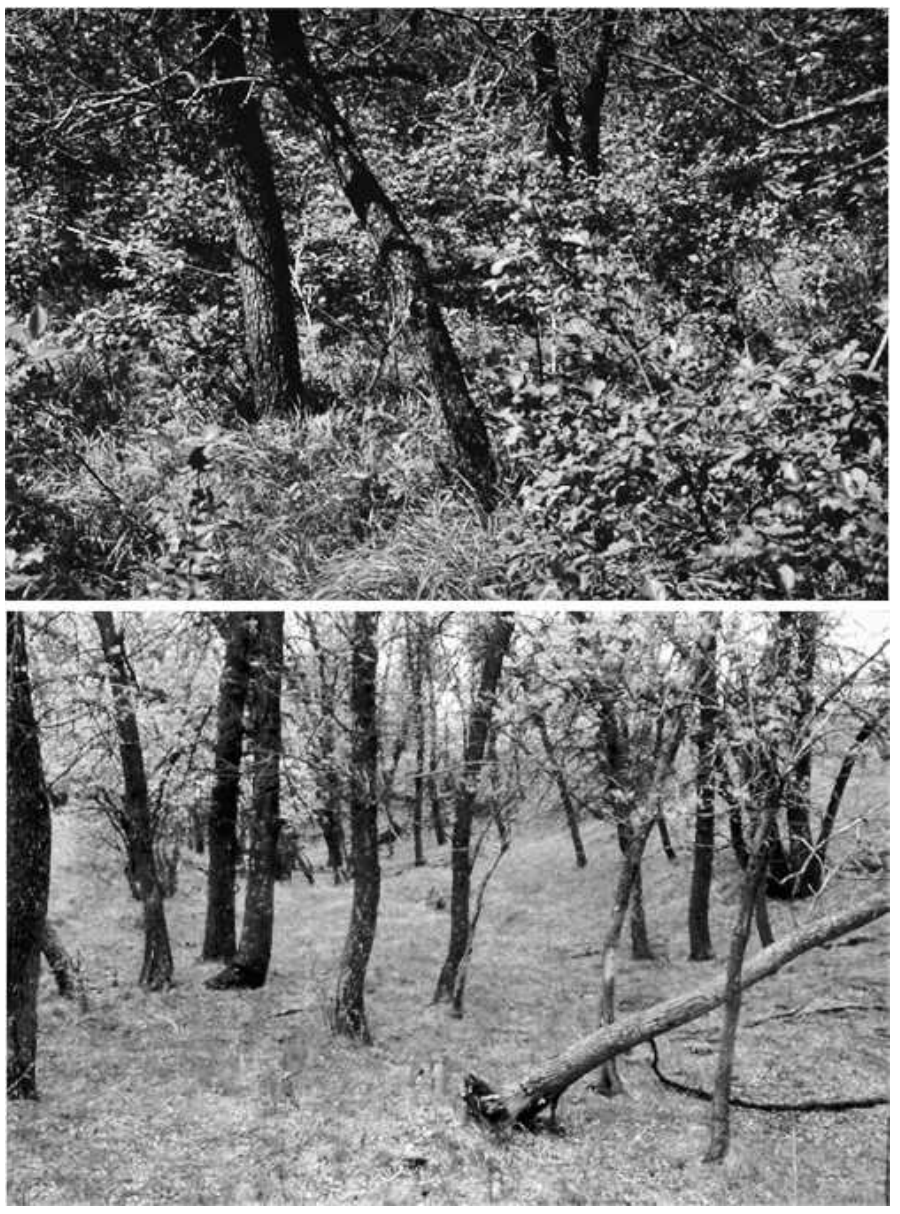

Figure 1. Undisturbed green ash woodland (above) and degraded woodland at the Willard study site (below).

undergrowth dominated by shrubs, native graminoids, and woodland forbs. Now, the majority of green ash woodlands in eastern Montana have open canopies with little or no tree regeneration, few shrubs in the understory, and a ground layer dominated by exotic sod-forming grasses (Fig. 1; Butler and Goetz 1984; Hansen et al. 1984; Sieg et al. 1984; Lesica 1989). Many stands have few trees younger than $80 \mathrm{yr}$ old (Lesica 2001). In extreme cases, green ash woodlands may become shrublands and meadows. These declining woodlands have lower bird diversity and lower densities of tree-nesting and shrub-nesting birds (Rumble and Gobeille 1998) and fewer forest-dwelling plants (Lesica 1989).

There are many potential causes for the decline of green ash in eastern Montana woodlands. Diseases such as heart rot (Perenniporia fraxinophila) and ash yellows as well as drought and late freezes contribute to broken boles and canopy dieback (Girard et al. 1987; Walla et al. 2000; Lesica et al. 2003). Little is known about the insect pests, but ash bark beetles (Hylesinus californicus) may kill trees by girdling them (P. Lesica and H. E. Atthowe, unpublished data, 2001). Fire can kill ash trees, although basal sprouting is the more common response (Lesica 2001). Woodcutting was common in the early part of the 20th century but is now minimal (P. Lesica, unpublished interviews with local residents, 2000). Livestock grazing is the most often cited cause for failure of tree regeneration in ash woodlands.
Differences among stands with different grazing histories suggest that livestock grazing lowers the canopy cover of tall shrubs (Butler and Goetz 1984; Hansen and Hoffman 1988), and this change is associated with lower densities of tree seedlings (Lesica 2001). Heavy browsing of seedlings and saplings reduces tree recruitment and leads eventually to opening of the canopy and dominance of the ground layer by exotic perennial sod-forming grasses (Butler and Goetz 1984; Butler et al. 1986; Uresk and Boldt 1986). Poor regeneration of green ash may also result from browsing by native ungulates. Prior to 1941 white-tailed deer in eastern Montana primarily inhabited the Yellowstone and Missouri river bottoms; however, in recent times populations have grown and extended their range beyond major rivers (Mussehl and Howell 1971). White-tailed deer now use ash woodlands heavily during winter months (MacCracken and Uresk 1984). The decline of green ash woodlands on the Great Plains is part of a global loss of forests and woodlands resulting from similar causes (Klein and Perkins 1988; Yates and Hobbs 1997; MacDougall et al. 2004).

Land managers are interested in restoring green ash woodlands regardless of the causes for the decline. Restoration hinges on regeneration of green ash, which would result in increased canopy cover and shade. Green ash may regenerate by vegetative basal sprouting or from seed. Basal sprouting of green ash is common at the western edge of its range. On average, $33 \%$ of green ash trees in east-central Montana woodlands had basal sprouts, and 30\% of the ash trees had more than one bole, suggesting that a minimum of one-third of the trees in these stands arose as basal sprouts (Lesica 2001). More than $90 \%$ of green ash trees had basal sprouts after being cut in an experimental study in western North Dakota (Uresk and Boldt 1986). Although basal sprouting is common, new green ash trees (genets) can only be recruited from seed, so acquiring new genetic variation and replacing dead trees depends on seedling recruitment. Recruitment of green ash from seed is uncommon in declining eastern Montana woodlands (Lesica 1989, 2001). The presence of seedlings and saplings was negatively associated with the presence of exotic sod grasses in the ground layer (Lesica 1989, 2001). This association points to the presence of dense grass sod as prohibiting tree recruitment and suggests that disturbing the sod might allow recruitment and survival of green ash from seed. Tree recruitment was reported to be reduced by competition with grass in many systems because grasses deplete soil moisture, thereby lowering seedling survival (Albertson and Weaver 1945; Van Auken and Bush 1997; Gordon and Rice 2000).

Fire has been suggested as a process that could facilitate regeneration of woodlands on the Great Plains (Abrams 1985; Girard et al. 1987; Lesica 1989) by opening sites in grass sod for tree seedling germination (McClaran and Bartolome 1989). However, there was no evidence that wildfire had a positive effect on green ash regeneration at seven sites in eastern Montana (Lesica 2003). Necessary disturbance could also be accomplished by either trampling or herbicide application. In an experiment conducted in a declining woodland, Uresk and Boldt (1986) found that densities of ash and elm seedlings were higher on plots disturbed by grazing compared to protected plots.

The purpose of this study was to test potential methods of restoring regeneration of green ash in declining woodlands of southeastern Montana. Specifically, can reducing exotic sod grass cover with herbicide or cattle grazing followed by seeding 


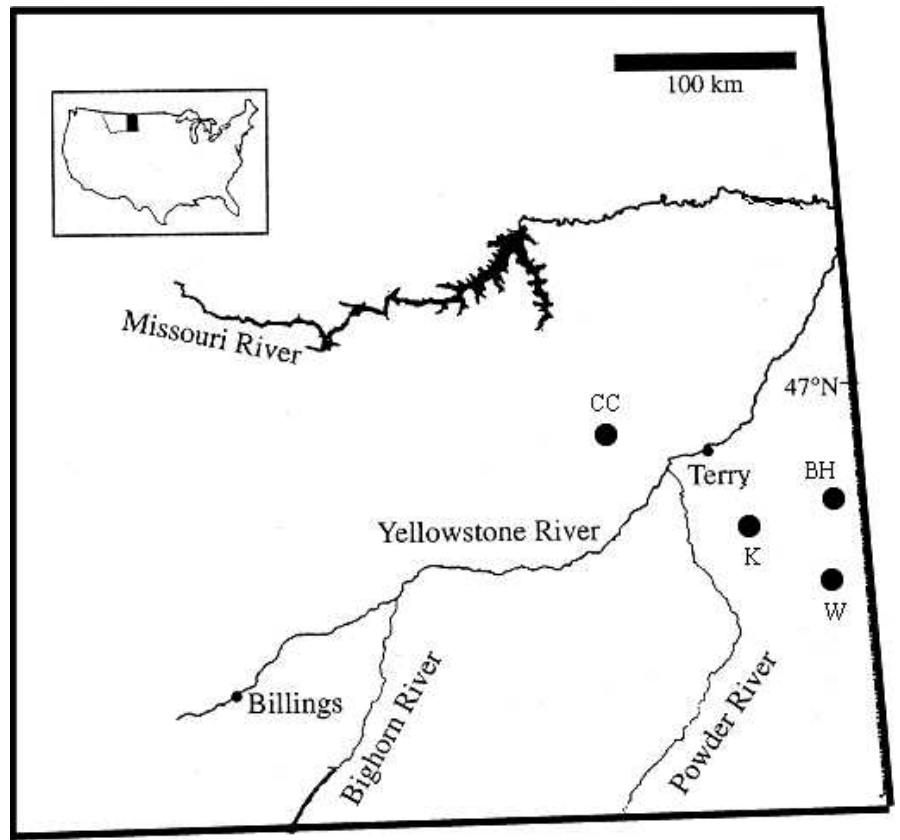

Figure 2. Location of four study sites in southeastern Montana: Big Hill $(\mathrm{BH})$, Cherry Creek (CC), Knowlton (K), and Willard (W).

be used to restore these woodlands in a manner that is practical for both public and private land managers? Additionally, the relationship between age, health, and the ability of green ash to produce basal sprouts was examined in order to determine whether coppicing (cutting old stems) green ash might be used to increase canopy cover of existing trees.

\section{METHODS}

\section{Study Areas}

Four study sites typical of nonreproducing green ash woodlands in southeastern Montana were selected for study (Fig. 2). Each was along a linear, ephemeral drainage ca. $300 \mathrm{~m}$ in length with homogeneous vegetation. These stands had few young trees, little chokecherry (Prunus virginiana L.) or other Prunus spp. in the understory, and ground-layer vegetation dominated by exotic forage grasses (e.g., Poa pratensis L., Bromus inermis Leyss., Agropyron cristatum [L.] Gaert., A. repens [L.] Beauv.). All of the study sites had a history of grazing by sheep in the early 1900 s and cattle thereafter. None of the stands showed any evidence of previous fire. Tree canopy cover ranged from $12 \%$ to $70 \%$ and varied among sites $\left(\mathrm{F}_{3,80}=14.2, P<0.001\right)$; mean tree canopy cover was $33 \%, 32 \%, 53 \%$, and $46 \%$ for Knowlton, Big Hill, Cherry Creek, and Willard, respectively. Landowners indicated that the hardwood draws at the Cherry Creek and Big Hill study sites were frequented by white-tailed deer (Odocoileus virginianus), whereas mule deer (Odocoileus hemionus) were most common at the Knowlton study site.

\section{Field Methods}

A 160-m-long macroplot with mature green ash of similar density and age-class distribution encompassing both sides of the drainage was located at each site in October 2003. Macroplots were fenced in the spring of 2004 to exclude cattle; fences were not high enough to exclude deer. Each macroplot was fenced in half and one randomly chosen half was grazed by cattle during the summer of 2004. Managers were asked to graze severely. The other half was excluded from grazing in 2004, and both halves were excluded from grazing thereafter. Four treatments and a control were replicated three times in randomly assigned $12.5-\mathrm{m}^{2}$ (2-m radius) circular plots in each macroplot in a split-block design. Treatments were 1) herbicide, 2) herbicide and fertilizer, 3) grazed only, 4) grazed and fertilizer, and 5) control (no herbicide, no fertilizer, no grazing). Descriptions of the treatments follow.

Grazing. Knowlton was grazed by 64 yearlings for $2.5 \mathrm{~d}$ in mid-August. Big Hill was grazed by 70 yearlings for $36 \mathrm{~h}$ in the latter half of June. Cherry Creek was grazed by 45 cow-calf pairs for $3.5 \mathrm{~d}$ in early September. Willard was grazed by 50 cow-calf pairs for $1 \mathrm{wk}$ in mid-August and again in late October.

Herbicide. Glyphosate $(100 \%)$ at a rate of $3.5 \mathrm{~L} \cdot \mathrm{ha}^{-1}$ was applied with a backpack sprayer in late May 2004.

Fertilizer. Low-nitrogen fertilizer (16:16:16) was applied at the manufacturer's prescribed rate $5.85 \mathrm{~kg} \cdot 100 \mathrm{~m}^{-2}$ to each sample plot in early June 2006 and again in 2007.

Green Ash Seeding. Seeds of green ash were broadcast into all plots at a rate of $17 \mathrm{seeds} \cdot \mathrm{m}^{-2}$ in mid-October 2004. There were no seedlings in any of the plots at Knowlton in May 2005, so these plots were reseeded at a rate of 9 seeds $\cdot \mathrm{m}^{-2}$ in midOctober 2005. Seeds of green ash were obtained from the Montana Department of Natural Resources and Conservation nursery in Missoula, Montana (Lot 264, stock originally from eastern Montana).

Rodent seed predation was deterred by placing three snap traps baited with walnuts and a poison bait station in each sample plot in October 2004. Each station was a 1-L plastic yogurt container with a $2.54-\mathrm{cm}$ (1-inch)-diameter hole drilled in the top and baited with $40 \mathrm{~g}$ of Ecolab rat and mouse exterminator (active ingredient, $0.005 \%$ diphacinone). In October 2005 ash seeds were coated with Hot Pepper Wax (10 $\mathrm{mL}$ in $250 \mathrm{~mL} \mathrm{H} \mathrm{H}_{2} \mathrm{O}$; active ingredient: capsicum) to deter rodents and with Flight Control $\left(10 \mathrm{~mL}\right.$ in $500 \mathrm{~mL} \mathrm{H}_{2} \mathrm{O}$; active ingredient: anthraquinone) to deter birds.

Total tree canopy cover was measured with a spherical densiometer from the center of each sample plot in 2005, and canopy cover of perennial graminoids, annual plants (grasses and forbs), and total herbaceous plants was visually estimated to the nearest 5\% in May 2004 and June 2005-2008. Total number of green ash seedlings were recorded in each plot in each year between 2005 and 2006. Green ash seedlings have large cotyledons (ca. $2 \mathrm{~cm}$ ) and were easily visible. There was an in situ green ash seed crop in 2006 and 2007, so the number of new recruits for 2007 and 2008 were also recorded. Height of 20052006 ash recruits were measured to the nearest $1 \mathrm{~cm}$ in 2008 .

Six randomly chosen green ash trees were sacrificed at each site except Willard to examine the relationship of age, size, and health to sprouting ability. Experimental trees were well outside of plots but in the same general area. A chain saw was used to cut the green ash with the greatest proportion of dead crown ca. $50 \mathrm{~cm}$ above ground level in October 2004, and the diameter of the 
stump was measured. Age of each tree was determined by counting growth rings from stump cross sections under a 10power microscope. Heart rot was not present in the base of any of the trees. Number of heart-rot sporocarps were recorded for each sample tree. Senescence of the canopy or dieback can be due to stress or self-shading, so percent senescence was estimated only for the upper half of the canopy of each tree. In October 2005 all sprouts greater then $1 \mathrm{yr}$ old were removed from experimental trees. In September 2008 the height of each sprout and the number of times it had been browsed as determined by the number of nodes with more than two shoots was recorded. Browsing was almost certainly done by deer because livestock were excluded by the fence, and browse lines were too high for rabbits.

\section{Data Analysis}

The association between the canopy cover of annual plants and ash recruitment was assessed with a linear regression model, as were relationships between overstory tree canopy cover and ash recruitment, survival, and growth. Recruitment, survival, and annual plant cover were rank-order transformed to conform to the assumptions of the tests. Changes in vegetal cover before (2004) and after (2005) grazing and herbicide treatments were assessed with paired-sample $t$ tests.

Ash recruitment from seed was the number of seedlings per plot the first $2 \mathrm{yr}$ following seeding $(2005,2006)$. There was no in situ seed produced in 2004 or 2005, so all of these seedlings were presumed to be from the experimental seeding because green ash is reported to have only a short-lived seed bank (Farrar 1995). Survival was number of survivors in 2008 with number of recruits in 2005-2006 as a covariate in analysis of variance (ANOVA) models ( 2008 survivors/2005-2006 recruits). Growth was measured as the height of 2005-2006 recruits in 2008.

Green ash recruitment and survival data could not be normalized to meet the assumptions of parametric tests, so effects of treatments on these dependent variables were assessed using nonparametric Kruskal-Wallis tests (Mann-Whitney for pairwise tests). Growth of green ash was analyzed by ANOVA with treatment and site as explanatory variables. The three levels of treatment were herbicide, grazing, and control. Fertilizer was not included in the models because separate analyses determined it had no effect on the dependent variables $(P>0.24$; see Results). No seedlings were present at Big Hill after 2006, so this site was omitted from the analysis of survival and growth.

ANOVA was used to test for differences among sites in size, age, and canopy dieback of experimental trees and sprout densities and browse rate (mean proportion of years browsing occurred). Stepwise linear regression (rejection $P>0.10$ ) modeling was used to determine the association between number of sprouts and age, diameter, canopy dieback, and number of sporocarps in the experimental trees across sites. Linear regression analysis was used to test the association between sprout height and browse rate.

\section{RESULTS}

\section{Effects of Herbicide and Grazing on Vegetation}

Grazing had little effect on the canopy cover of perennial grasses, annuals, or total vegetal cover across all sites. There

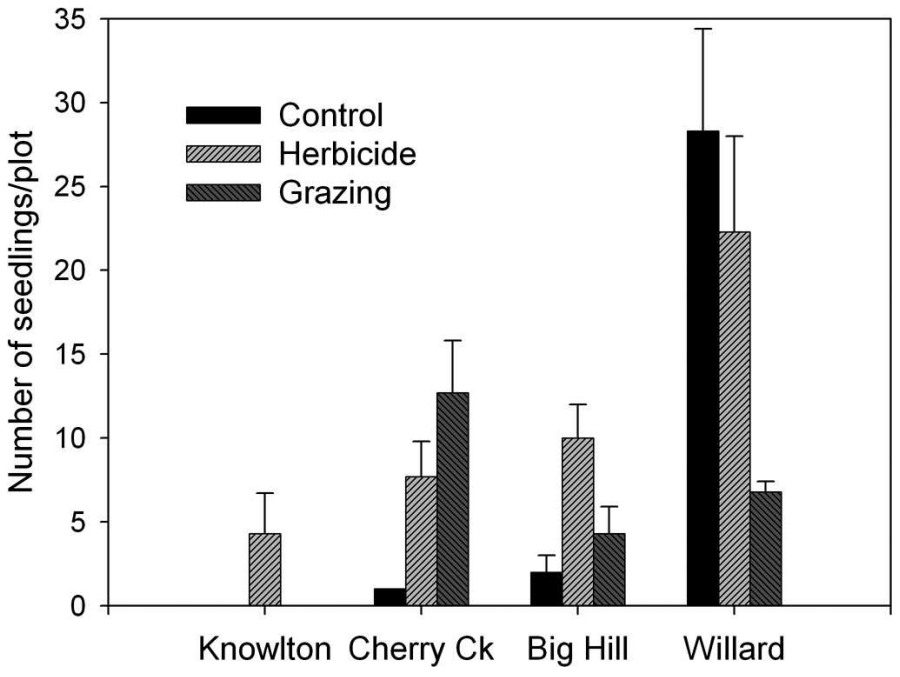

Figure 3. Recruitment of green ash seedlings (+SE) from 2004 and 2005 in grazed, herbicide-treated, and control plots at the four study sites.

was an increase of $4 \%$ in total herbaceous cover $1 \mathrm{yr}$ after the grazing treatment $(t=2.2, P=0.036)$; the increase in perennial grass cover $(5 \%)$ was marginally significant $(P=0.09)$, but the increase in annual $(1 \%)$ grass cover was not $(P=0.21)$. The increased cover of perennial grass following grazing probably reflects the total absence of spring grazing in 2005. Herbicide application had significant effects on the vegetation; total cover declined $60 \%$ across the four sites $(t=8.2, P<0.001)$. Perennial, almost entirely exotic, grass cover declined from a mean of $82 \%(\mathrm{SE}=2 \%)$ in 2004 across all study sites to $5 \%$ $(\mathrm{SE}=2 \%)$ following application in $2005(t=27.6, P<0.001)$. Perennial grass cover rebounded to $48 \%(\mathrm{SE}=6 \%)$ by 2008 across all sites. There was a concomitant increase in annuals (grasses and forbs) from a mean of $1 \%(\mathrm{SE}<1 \%)$ in 2004 to $25 \%(\mathrm{SE}=6 \%)$ in 2005 and $2008(t=3.8, P=0.001)$. These changes varied among sites with Knowlton and Cherry Creek showing the greatest increase in annuals, due primarily to an increase in brome grasses (Bromus spp.).

\section{Green Ash Regeneration From Seed}

There was no local green ash seed produced in 2004-2005 (P. Lesica, personal observation), and green ash is thought to have only a short-lived seed bank (Farrar 1995), so ash seedlings recruited in experimental plots in 2005 and 2006 were considered the result of the seeding. The effect of treatment on green ash seedling recruitment was significant $(H=6.3$, $\mathrm{df}=2, P=0.043)$. Compared to controls, the number of recruits was greater in herbicide plots $(U=82, \mathrm{df}=1$, $P=0.036)$ but not grazed plots $(U=126, \mathrm{df}=1, P=0.55)$ across all sites (Fig. 3).

Annual plants increased in herbicide plots (see above), with a mean canopy cover of $37 \%$ in 2006, and canopy cover of annual plants was marginally positively associated with recruitment of green ash in these plots $\left(R^{2}=0.06, P=0.059\right)$. Green ash seed crops were strong in 2006-2007. Recruitment presumably from in situ seed rain resulted in 36 new recruits in 2007,34 of which occurred in herbicide-treated plots. Of the 151 new recruits at Cherry Creek in 2008, 136 were found in herbicide plots $(t=3.6, P=0.015)$. Green ash recruitment was 
positively associated with tree canopy cover across all treatments and sites $\left(R^{2}=0.17, P=0.001\right)$.

All green ash seedlings died at Big Hill by 2007, so this site was not included in the following analyses. There was an effect of treatment on survival $(H=8.9$, df $=2, P=0.012)$. Survival of 2005-2006 ash seedlings over the duration of the study was $28 \%$ in herbicide plots but only $1 \%$ in control plots across the three sites ( $U=58, \mathrm{df}=1, P=0.041)$. The effect of grazing on ash seedling survival was not significant $(U=69, \mathrm{df}=1, P=0.56)$. Fifty-seven of the $206(28 \%)$ green ash recruited in herbicide plots in 2005 and 2006 survived until 2008, but only 7 of the 205 (3\%) survived in nonherbicide plots (grazed + control). Survival of ash seedlings in herbicide plots was positively associated with canopy cover of annual plants as measured in $2006\left(R^{2}=0.16, P=0.005\right)$, but was not associated with tree canopy cover $(P=0.17)$.

Green ash seedlings that germinated in 2005-2006 varied from $2 \mathrm{~cm}$ to $14 \mathrm{~cm}$ in height with a mean of $6.2 \mathrm{~cm}$ $(\mathrm{SE}=0.2 \mathrm{~cm})$ in 2008 . There was no effect of fertilizer on ash growth across the three study sites $(P=0.28)$; green ash from fertilized plots averaged $7.1 \mathrm{~cm}$ high $(n=23)$, whereas the mean from unfertilized plots was $5.9 \mathrm{~cm}$ high $(n=68)$ across all sites. There was an effect of site on green ash growth $\left(\mathrm{F}_{2,85}=6.1, \quad P=0.003\right)$ with plants from Cherry Creek averaging $1.5 \mathrm{~cm}$ shorter than at the other two sites. The effect of fertilizer depended on site (site $\mathrm{X}$ fertilizer interaction $\left.\mathrm{F}_{2,85}=4.5, P=0.013\right)$. At Willard, fertilized ash seedlings averaged $8.8 \mathrm{~cm}$ high compared to $5.7 \mathrm{~cm}$ for those in unfertilized plots $\left(\mathrm{F}_{1,29}=8.3, P=0.007\right)$. There was no effect of fertilizer at the other two sites $(P>0.63)$. There was no difference in the height of green ash seedlings among herbicide, grazed, and control plots $(P=0.84)$. There was an insignificant positive association between tree canopy and seedling height without accounting for differences among sites $(P=0.12)$.

\section{Recruitment From Coppiced Green Ash}

All 18 green ash trees cut down in fall 2004 produced sprouts in 2005, and all but one were still alive in 2008. The bole diameter of experimental trees varied among sites $(P=0.075)$. Green ash cut down at Knowlton averaged $30.5 \mathrm{~cm}$ in diameter compared to $20.4 \mathrm{~cm}$ and $23.9 \mathrm{~cm}$ at Big Hill and Cherry Creek, respectively, and this difference was significant $\left(\mathrm{F}_{1,15}=5.5, P=0.033\right)$. Age of trees did not vary among the three sites $(\bar{x}=84, \mathrm{SE}=5, P=0.13)$; nor did amount of crown dieback $(\bar{x}=66 \%, \mathrm{SE}=4 \%, P=0.47)$.

The number of sprouts produced in 2005 varied among sites $\left(\mathrm{F}_{2,15}=5.2, P=0.02\right)$. Sprout density was 16 per stump at Cherry Creek, significantly greater than the other two sites $\left(\mathrm{F}_{1,15}=8.9, P=0.009\right)$. Sprout density between Knowlton $(\bar{x}=8)$ and Big Hill $(\bar{x}=11)$ did not differ $\left(\mathrm{F}_{1,15}=1.5\right.$, $P=0.24)$. Both proportion of dieback and number of sporocarps were significant factors in the best linear regression model for basal sprout number $\left(R^{2}=0.21, P=0.040\right)$; number of sprouts was negatively associated with the extent of crown dieback but positively associated with the number of sporocarps. There was no relationship between number of sprouts produced in 2005 and the age or diameter of the trees $(P>0.22)$.

Sprouts were longer at Knowlton compared to the other two sites throughout the course of the study (Fig. 4). Unbrowsed stump sprouts at Knowlton increased by an average of

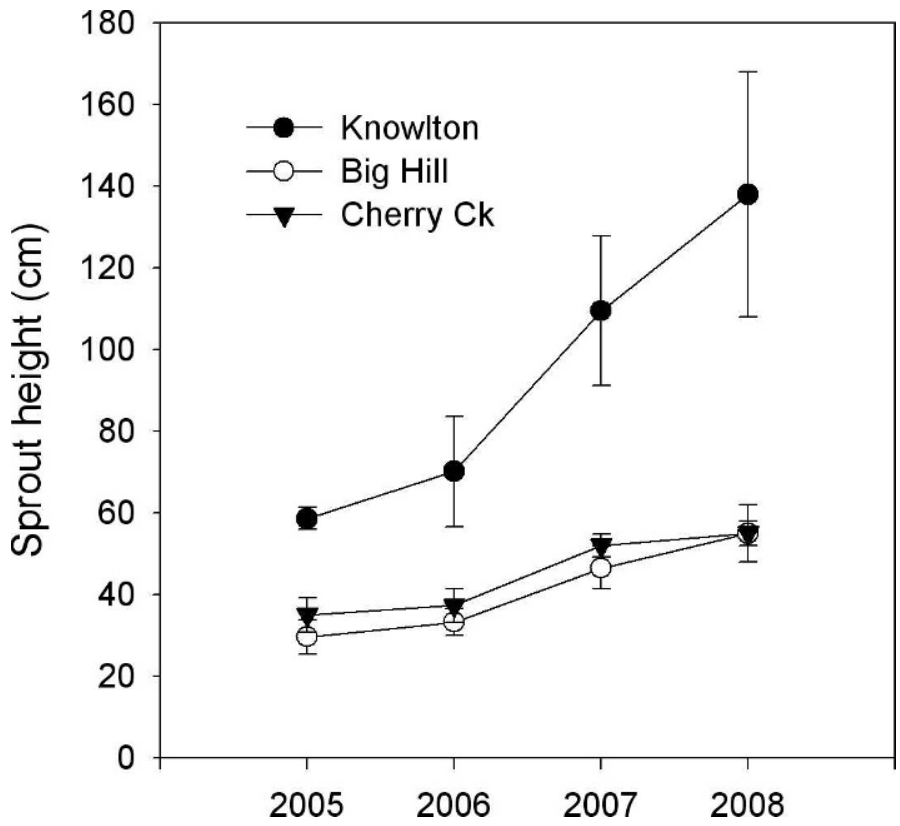

Figure 4. Mean height ( \pm SE) of green ash basal sprouts at three study sites in 2005-2008.

$40 \mathrm{~cm} \cdot \mathrm{yr}^{-1}$, and varied between $11 \mathrm{~cm} \cdot \mathrm{yr}^{-1}$ and $76 \mathrm{~cm} \cdot \mathrm{yr}^{-1}$. The mean number of times a sprout was browsed between 2004 and 2008 differed among sites $\left(\mathrm{F}_{21,14}=12.9, P=0.001\right)$. Mean browse rate (proportion of years browsing occurred) was 0.13 at Knowlton $(n=40, \mathrm{SE}=0.03)$, significantly less than Big Hill $(0.72 \pm 0.04, n=39)$ and Cherry Creek (0.65 $\pm 0.03, n=83$; $\left.\mathrm{F}_{1,159}=173.4, P<0.001\right)$; however, the latter two sites did not differ $(P=0.15)$. Mean sprout height in 2008 was negatively associated with browse rate across all three sites $\left(R^{2}=0.34\right.$, $P<0.001)$.

\section{DISCUSSION}

\section{Regeneration From Seed}

Restoration of declining woodland canopies in the northwestern Great Plains will depend on recruitment of green ash stems. My results indicate that a single herbicide treatment to reduce grass cover followed by seeding promoted establishment of green ash in woodlands with a dense sod of exotic perennial grasses. The effect of herbicide on 2004-2005 first-year green ash recruitment was positive, although it was not consistent across sites (Fig. 3). Seedling survival for 3-4 yr was $28 \%$ in herbicide plots but less than $4 \%$ in plots that did not receive herbicide. These results suggest a significant negative effect of exotic perennial grass cover on green ash seedling survival and the efficacy of herbicide treatment in ameliorating this effect. Herbicide promoted the abundance of annual plants, especially exotic brome grasses. However, these annuals replaced exotic perennials, and my results suggest that they did not negatively affect the recruitment or survival of ash seedlings. Grazing prior to seeding did little to reduce perennial grass cover after the first year, and my results suggest that it increased neither early recruitment nor survival of green ash seedlings.

Unfortunately, growth of green ash seedlings was poor, averaging only ca. $6 \mathrm{~cm}$ after 3-4 yr, even though under good 
conditions (e.g., roadside ditches) they may grow as much as $20 \mathrm{~cm} \cdot \mathrm{yr}^{-1}$ (P. Lesica, personal observation). Root growth of seedlings was also slow; root length of 4-yr seedlings excavated from Willard averaged only $9.8 \mathrm{~cm}(\mathrm{SE}=1.5 \mathrm{~cm}, n=5)$. This poor growth was in spite of normal spring precipitation over the course of the study at the four sites. There was no evidence that seedlings were browsed by deer. It seems likely that such slow-growing plants would perish in competition with perennial grasses that began to reoccupy herbicide-treated areas after only a few years. Furthermore, quick growth is needed to escape deer browsing (Groninger et al. 2004). Fertilizer enhanced green ash seedling growth slightly at one site but could have a similar positive effect on competing vegetation.

Necessary conditions for successful regeneration of green ash from seed may be rare. The northwestern Great Plains is a semiarid environment, marginal for tree growth (Albertson and Weaver 1945), and green ash is at the extreme arid periphery of its range in eastern Montana. Green ash is a tree of humid to subhumid climates, occurring mainly in bottom lands (Fowells 1965; Fitzgerald et al. 1975), so it is reasonable to assume that hydrology is an important limiting factor for the growth of green ash in eastern Montana. Hydrologic regimes and depth to water table have been shown to control recruitment and growth of related ash species in Europe (Dufour and Piegay 2008). Hydrologic conditions conducive to recruitment and growth of green ash seedlings in eastern Montana may have been sporadic, even prior to the introduction of exotic sod grasses into the woodland understory (Girard et al. 1987). These conditions may be even less common now in a warmer climate (Guertin et al. 1997; Harris et al. 2006). The study areas had above-average spring (March-May) moisture over the course of the study, but winter (December-February) precipitation was $28 \%$ lower than the 20th-century mean (NOAA data accessed online; Western Regional Climate Center 2009). Perhaps more importantly, the winters averaged nearly $2^{\circ} \mathrm{C}$ warmer than in the last century. These conditions probably reduced snow accumulations, early spring flows, and the deep water penetration into the soil likely needed for prolonged growth of ash seedlings. Such changes in hydrology could reduce the opportunity for recruiting green ash from seed into the canopy in many woodlands.

\section{Regeneration by Coppicing}

Experimentally cut green ash trees sprouted vigorously and grew substantially in the absence of deer browsing. At the recorded mean growth rate of $40 \mathrm{~cm} \cdot \mathrm{yr}^{-1}$, green ash sprouts would reach average tree height of $7 \mathrm{~m}$ (Lesica 2001) in less than 20 yr. Similar results for green ash were obtained in deer exclosures in western North Dakota (Uresk and Boldt 1986; D. Uresk, unpublished data, 2007). Basal sprouting may be the dominant form of reproduction for green ash in the northwestern Great Plains even without the human-caused stressors of the past century. Although recruitment of green ash from seed has occurred recently in some woodlands, dendrochronological studies suggest that the last major recruitment event across eastern Montana occurred ca. 70-80 yr ago as a result of stump sprouting during a time when deer populations were low (Lesica 2001). Vegetative reproduction often predominates at the margin of a species' range (Dorken and Eckert 2001; Eckert
2002; Beatty et al. 2008), where it presumably enhances persistence in the face of marginal ecological conditions (Bond and Midgley 2001).

Green ash sprouts at two of three study sites were regularly browsed by white-tailed deer and grew very little over the $4 \mathrm{yr}$ of the study (Fig. 4). I do not know whether the lack of browsing at the one site dominated by mule deer was anomalous or indicative of a behavioral dichotomy between the two species. Regardless, my results indicate that coppicing is not likely to rejuvenate tree canopies where deer browsing is intense. Studies in deciduous or mixed forests in central and eastern North America also suggest that overbrowsing by white-tailed deer can impact forest canopy composition. Gubanyi et al. (2008) found that deciduous forests in southeastern Nebraska with high white-tailed deer densities had fewer ash (Fraxinus sp.) saplings compared to forests with low deer densities. Fitzgerald et al. (1975) reported that deer browsing was a significant threat to green ash growth and survival in Georgia. Deer have increased in abundance over the past century because of increased habitat, regulated hunting, and decline of predators, and are thought to be at greater than presettlement densities in many areas (Côte et al. 2004). Whitetailed deer populations have increased dramatically in many areas of the upper Midwest and the Appalachian Mountains. Their presence has curtailed regeneration of preferred tree species, altering structure, composition, and productivity of stands (Aldous 1952; Stoeckeler et al. 1957; Anderson and Loucks 1979; Alverson et al. 1988). White-tailed deer populations in eastern Montana have grown and extended their range into the uplands during the latter part of the past century (Mussehl and Howell 1971).

Results of this and other studies (Uresk and Boldt 1986; D. Uresk, unpublished data, 2007) indicate that old, diseased trees will readily produce basal sprouts after being cut to the ground. On average, ash heart rot (Perenniporia fraxinophila) invades the base of the bole less than $25 \%$ of the time in eastern Montana (Lesica et al. 2003), so most trunks will be sound where they are cut and will produce vigorous, new stems. Green ash sprouts can be expected to obtain heights of 7-8 m in 20-25 yr in eastern Montana and adjacent North Dakota if unbrowsed (Fig. 4; D. Uresk, unpublished data, 2007).

\section{IMPLICATIONS}

My study suggests that restoration of green ash from seed in eastern Montana woodlands will be difficult at best, requiring either a coincidence of increasingly unlikely biological and environmental conditions or large expenditures of time and money. Even under optimum hydrologic conditions, biological factors may preclude ash regeneration. Reducing competition with perennial grasses will be important for recruitment if adequate spring moisture is needed for growth of green ash. Populations of herbivores (cattle, deer, rabbits, etc.) will need to be low for several consecutive years to allow survival. Environmental changes such as exotic invasions and alterations in patterns of herbivory or climate can result in alternative stable states that make restoring degraded ecosystems to past composition and structure difficult or impossible, especially at the stressful edge of ecological tolerances (Suding et al. 2004; 
Harris et al. 2006). All of these types of changes appear to be playing a role in reducing the recruitment of green ash and making the degraded understory condition a stable state in eastern Montana woodlands. Coppicing cannot produce more trees, but it can increase tree canopy cover by replacing diseased or weakened trees with new and more vigorous boles and branches. Increasing green ash canopy cover by coppicing could increase shade and shade-tolerant species while weakening shade-loving exotic grasses, which might, in turn, make ash recruitment from seed more likely. Successful coppicing would require controlling livestock to minimize browsing and may not be possible in areas with high densities of white-tailed deer.

Maintaining green ash woodlands in good condition should be given priority because rejuvenating the canopies of degraded green ash woodlands will be difficult under current conditions. Livestock should be managed to protect the understory and the shady environment it provides the ground layer. A shaded ground layer will encourage growth of shade-tolerant species such as green ash and discourage shade-intolerant exotic grasses. A dense shrub layer will also discourage browsing of young trees by cattle and deer. Winter use is thought to be less damaging than grazing during the growing season (Severson and Boldt 1978). Excluding cattle from ash woodlands using movable electric fence may be possible for some livestock growers.

\section{ACKNOWLEDGMENTS}

I am grateful to Adam Carr, Louise DeMontingy, Dale Tribby, Dan Brunkhorst, Kristi DuBois, Ann Fisher, and Carla Lawrence for help in the field and logistical support. Monte Herzog, Fred Hoff, Rob and Judy Reukauf and Jerry and Kathy Sikorski gave me permission to work on their land. Jon Justin (Montana Department of Natural Resources and Conservation) provided the green ash seed. Peter Kolb helped with study design. Pamela Kittelson and three anonymous reviewers provided many helpful comments on the manuscript.

\section{LITERATURE CITED}

Abrams, M. D. 1985. Fire history of oak gallery forests in a northeast Kansas tallgrass prairie. American Midland Naturalist 114:188-191.

Albertson, F. W., AND J. E. Weaver. 1945. Injury and death or recovery of trees in prairie climate. Ecological Monograph 15:395-433.

ALdous, S. E. 1952. Deer browse clipping study in the Lake States region. Journal of Wildlife Management 15:401-409.

Alverson, W. S., D. M. Waller, and S. L. Solheim. 1988. Forests too deer: edge effects in northern Wisconsin. Conservation Biology 2:348-358.

Anderson, R. C., And O. L. Loucks. 1979. White-tail deer (Odocoileus virginicus) influence on structure and composition of Tsuga canadensis forests. Journal of Applied Ecology 16:855-861.

Beatty, G. M., P. M. McEvoy, 0. Sweeney, and J. Provan. 2008. Range-edge effects promote clonal growth in peripheral populations of the one-sided wintergreen, Orthilla secunda. Diversity and Distributions 14:546-555.

Boldt, C. E., D. W. UresK, and K. E. SeVERSon. 1978. Riparian woodlands in jeopardy on the northern High Plains. In: R. R. Johnson and J. F. McCormick [EDs.]. Proceedings of the national symposium on strategies for protection and management of floodplain wetlands and other riparian ecosystems. General Technical Report W0-12. Washington, DC, USA: USDA Forest Service. p. 184-189.

Bond, W. J., AND J. J. Midgley. 2001. Ecology of sprouting in woody plants: the persistence niche. Trends in Ecology and Evolution 16:45-51.

Butler, J., and H. Goetz. 1984. Influence of livestock on the composition and structure of green ash communities in the Northern Great Plains. In: D. L. Noble and R. P. Winokur [EDS.]. Wooded draws: characteristics and values for the Northern Great Plains. Rapid City, SD, USA: South Dakota School of Mines and Technology. p. 44-49.

Butler, J., H. Goetz, and J. L. Richardson. 1986. Vegetation and soil-landscape relationships in the North Dakota badlands. American Midland Naturalist 116:378-386.

Côte, S. D., T. P. Rooney, J. Tremblay, C. Dussault, and D. Waller. 2004. Ecological impacts of deer overabundance. Annual Review of Ecology, Evolution and Systematics 35:113-147.

Dorken, M., AND C. G. ECKERT. 2001. Severely reduced sexual reproduction in northern populations of a clonal plant, Decodon verticillatus (Lythraceae). Journal of Ecology 89:339-350.

Dufour, S., And H. Piegay. 2008. Geomorphological controls of Fraxinus excelsior growth and regeneration in floodplain forests. Ecology 89:205-215.

Eckert, C. G. 2002. The loss of sex in clonal plants. Evolutionary Ecology 15:501-520.

FarRaR, J. L. 1995. Trees in Canada. Markham, Ontario, Canada: Fitzhenry \& Whiteside. $502 \mathrm{p}$.

Fitzgerald, C. H., R. P. Belanger, and W. W. Lester. 1975. Characteristics and growth of natural green ash stands. Journal of Forestry 73:486-488.

Fowells, H. A. 1965. Silvics of forest trees of the United States. Agriculture Handbook No. 271. Washington, DC, USA: USDA Forest Service. 762 p.

Girard, M. M., H. Goetz, And A. J. BuJgstad. 1987. Factors influencing woodlands of southwestern North Dakota. Prairie Naturalist 19:189-198.

Gordon, D. R., AND K. J. Rice. 2000. Competitive suppression of Quercus douglasii (Fagaceae) seedling emergence and growth. American Journal of Botany 87:986-994.

Great Plains Flora Association. 1986. Flora of the Great Plains. Lawrence, KS, USA: University Press of Kansas. $1392 \mathrm{p}$.

Groninger, J. W., S. G. Baer, D. A. Babassana, and D. H. Allen. 2004. Planted green ash (Fraxinus pennsylvanica Marsh.) and herbaceous vegetation responses to initial competition control during the first 3 years of afforestation. Forest Ecology and Management 189:161-170.

Gubanyi, J. A., J. A. Savidge, S. E. Hygnstrom, K. C. Vercauteren, G. W. Garabrandt, AND S. P. KoRTE. 2008. Deer impact on vegetation in natural areas in southeastern Nebraska. Natural Areas Journal 28:121-129.

Guertin, D. S., W. E. Easterling, and J. R. Brandle. 1997. Climate change and forests in the Great Plains. BioScience 47:287-295.

Hansen, P. L., and G. R. Hoffman. 1988. The vegetation of the Grand River/Cedar River, Sioux, and Ashland Districts of the Custer National Forest: a habitat type classification. General Technical Report RM-157. Fort Collins, C0, USA: USDA Forest Service. 68 p.

Hansen, P. L., G. R. Hoffman, and A. J. Buugstad. 1984. The vegetation of Theodore Roosevelt National Park, North Dakota: a habitat type classification. General Technical Report RM-113. Fort Collins, C0, USA: USDA Forest Service. 35 p.

Harris, J. A., R. J. HobBS, E. HigGS, AND J. Aronson. 2006. Ecological restoration and global climate change. Restoration Ecology 14:170-176.

HodorfF, R. A., AND C. H. SiEg. 1986. Bird species associated with green ash woodlands in the Slim Buttes, South Dakota. South Dakota Bird Notes 38:56-60.

Klein, R. M., and T. D. Perkins. 1988. Primary and secondary causes and consequences of contemporary forest decline. Botanical Review 54:1-43.

LESICA, P. 1989. The vegetation and condition of upland hardwood forests in eastern Montana. Proceedings of the Montana Academy of Sciences 49:45-62.

LesICA, P. 2001. Recruitment of Fraxinus pennsylvanica in eastern Montana woodlands. Madrono 48:286-292.

LesICA, P. 2003. Effects of wildfire on recruitment of Fraxinus pennsy/vanica in eastern Montana woodlands. American Midland Naturalist 149:258-267.

Lesica, P., H. E. Atthowe, and F. M. Dugan. 2003. Incidence of Perenniporia fraxinophila and its effects on green ash (Fraxinus pennsylvanica) woodlands in eastern Montana, USA. Forest Ecology and Management 182:153-159.

MacCracken, J., and D. W. Uresk. 1984. Big game habitat use in southeastern Montana. Prairie Naturalist 16:135-139.

MacDougall, A. S., B. R. BeCKWith, and C. Y. Maslovat. 2004. Defining conservation strategies with historical perspectives: a case study from a degraded oak grassland ecosystem. Conservation Biology 18:455-465. 
McClaran, M. P., and J. W. Bartolome. 1989. Fire-related recruitment in stagnant Quercus douglasii populations. Canadian Journal of Forest Research 19:580-585.

MusseHL, T., AND F. Howell. 1971. Game management in Montana. Helena, MT, USA: Montana Game and Fish Department.

Rumble, M. A., and J. E. Gobeille. 1998. Bird community relationships to succession in green ash (Fraxinus pennsylvanica) woodlands. American Midland Naturalist 140:372-381.

Rumble, M. A., C. H. Sieg, D. W. Uresk, and J. Javersak. 1998. Native woodlands and birds of South Dakota: past and present. Research Paper RMRS-RP-8. Fort Collins, CO, USA: USDA Forest Service. $11 \mathrm{p}$.

Severson, K. E., And C. E. Boldt. 1978. Cattle, wildlife and riparian habitats in the western Dakotas. In: Management and use of northern plains rangeland. Proceedings of the Regional Rangeland Symposium; 27-28 February 1978; Bismark, ND, USA. Dickinson, ND, USA: North Dakota State University. p. 90-103.

Sieg, C. H., R. A. Hodorff, and R. L. Linder. 1984. Stand condition as a variable influencing wildlife use of green ash woodlands. In: D. L. Noble and R. P. Winokur [EDS.]. Wooded draws: characteristics and values for the Northern Great Plains. p. 36-39.
Stoeckeler, J. H., R. O. Strothmann, and L. W. Krefting. 1957. Effect of deer browsing on reproduction in northern hardwood-hemlock type in northeastern Wisconsin. Journal of Wildlife Management 21:75-80.

Suding, K. N., K. L. Gross, and G. R. Houseman. 2004. Alternative states and positive feedbacks in restoration ecology. Trends in Ecology and Evolution 19:46-53.

URESK, D. W., AND C. E. BoLdT. 1986. Effects of cultural treatments on regeneration of native woodlands on the northern High Plains. Prairie Naturalist 18:193-202.

Van Auken, Q. W., ANd J. K. Bush. 1997. Growth of Prosopis glandulosa in response to changes in aboveground and belowground interference. Ecology 78:1222-1238.

Walla, J. A., W. R. Jacobi, N. A. Tisserat, M. 0. Harrell, J. J. Ball, G. B. Neill, D. A. Reynard, Y. H. Guo, and L. Spiegel. 2000. Condition of green ash, incidence of ash yellows phytoplasmas, and their association in the Great Plains and Rocky Mountain regions of North America. Plant Disease 84:268-274.

Western Regional Climate Center. 2009. Historical climate information. Available at: http://www.wrcc.dri.edu/. Accessed 15 January 2009.

Yates, C. J., AND R. J. HobBS. 1997. Temperate eucalypt woodlands: a review of their status, processes threatening their persistence and techniques for restoration. Australian Journal of Botany 45:949-973. 